\title{
Crustacean microcoprolites from the Upper Jurassic-Lower Cretaceous of the Neuquén Basin, Argentina: Systematics and biostratigraphic implications
}

Diego A. Kietzmann, Joachim Blau, Diana E. Fernandez, and Ricardo M. Palma

Acta Palaeontologica Polonica 55 (2), 2010: 277-284 doi: http://dx.doi.org/10.4202/app.2009.0094

As a result of a microfacial study in the outer and middle ramp deposits of the Vaca Muerta Formation (lower Tithonian-upper Valanginian), four ichnotaxa of crustacean microcoprolites are described: Palaxius azulensis Kietzmann isp. nov., Palaxius caracuraensis Kietzmann isp. nov., Helicerina? isp. A. aff. Helicerina siciliana and Helicerina isp. B. They represent one of the first records of crustacean microcoprolites for the Neuquén Basin and Argentina. Helicerina is reported for the first time from the Upper Jurassic and Lower Cretaceous of South America. It is inferred that Palaxius ichnospecies were produced by callianassids, while Helicerina ichnospecies could be produced by decapods of Mecochiridae, Erymidae, and/or Nephropidae affinity. Two assemblages of crustacean microcoprolites are recognised, a middle Tithonian to lower Berriasian Palaxius-dominated assemblage and an early to late Valanginian Helicerina-dominated assemblage.

Key words: Crustacean microcoprolites, Palaxius, Helicerina, Jurassic-Cretaceous, Vaca Muerta Formation, Neuquén Basin, Argentina.

Diego A. Kietzmann [diegokietzmann@gl.fcen.uba.ar], Diana E. Fernández [elizabeth@gl.fcen.uba.ar ], and Ricardo M. Palma [palma@gl.fcen.uba.ar], Departamento de Ciencias Geológicas, Facultad de Ciencias Exactas y Naturales, Universidad de Buenos Aires, Ciudad Universitaria, Pabellón II, 1428 Buenos Aires, Argentina, and Consejo Nacional de Investigaciones Científicas y Técnicas - CONICET; Joachim Blau [joachim.blau@geolo.uni-giessen.de], Feldbergstrasse 5, 61191 Rosbach-Rodheim, Germany. 
distribution, and reproduction in any medium, provided the original author and source are credited.

Fof Full text $(575.9 \mathrm{kB})$ 